\title{
PATAKFALVI-CZIRJÁK ÁGNES*
}

\section{Centenáriumi konferencia Bukarestben}

О nmagában is érdekes kérdés, hogy egy kelet-európai ország hogyan idézi fel a 21. században a „nemzeti egység” százéves évfordulóját. Romániában látszólag az egész ország ünnepel - a kormánypalotát beborító trikolór csak az egyik jele az ünnepi felkészülésnek, a gyógyszertárak (Dona), ${ }^{1}$ sörmárkák (például a Bürger), de még a román repülőtársaság is emlékezik. ${ }^{2}$ Centenáriumi programokkal készülnek az iskolák, a múzeumok, az akadémia, sőt még a kormányellenes tömegtüntetések résztvevöit is megihlette a kerek évforduló. Olyannyira, hogy a tömegben megjelenő, sorozatgyártott transzparensen a nemzetiszínü 100-as számjegy a két nullából egy bilincset formál, utalva a politikai korrupció miatti közfelháborodásra. ${ }^{3}$

A Society for Romanian Studies (SRS) idei tudományos konferenciájának témáját is természetesen ez az apropó adta. A tudományos találkozó címe egyszerre utalt az esemény egyik fösodrát adó történészi szemléletre, ugyanakkor annak a ,jövőtervezésben” betöltött szerepére is. Az „Elöretekintés a múlton keresztül” (Looking forward through the past) kissé szofisztikált elnevezésnek tünhet egy ilyen méretű esemény számára, azonban a címválasztás jól megragadja a tudományos tudás szándékolt pozicionálását a múltfeldolgozás és a jövőtervezés kapcsán.

Az SRS több száz, Romániával foglalkozó kutatót látott vendégül az egész világból, az előadások, könyvbemutatók és viták nyelve

\footnotetext{
* A szerző az MTA TK Kisebbségkutató Intézetének fiatal kutató munkatársa. Email: patakfalvi-czirjak.agnes@tk.mta.hu ${ }^{1}$ https://farmaciiledona.ro/campanii/s-rb-torim-centenarul-marii-uniri-la-albaiulia-I137

2 L. Tarom https://www.tarom.ro/stiri/tarom-anul-centenarului-unim-regiunileistorice-ale-romaniei-pe-calea-aerului)

${ }^{3}$ https://www.cotidianul.ro/decizia-ccr-scoate-oamenii-in-strada/
}

REGIO 26. évf. (2018) 2. szám 222-226. 
ezért az angol volt. A konferencia az ASE-n (Academia de Studii Economice), a bukaresti Közgazdaságtudományi Egyetem központi, a Piaţa Romană egyik meghatározó épületében kapott helyet. Az elöadásokat nagyjából három kategóriába lehetett sorolni: a történettudományi kérdéseket felvető panelekbe, a kortárs folyamatokat vizsgálók csoportjába, illetve egy tudományfilozófiai vagy ontológiai irányt követő kategóriába. Az I. világháború emlékezete, a modern Románia létrejötte (vagyis az új területek integrációjának kérdése), a két világháború közötti Románia geopolitikai helyzete hasonló súllyal jelent meg, mint az elitek, a vallási vagy diákmozgalmak szerepe Nagy-Románia létrejöttében. A kortárs témák között találhattuk a nemzeti identitás és kultúra vizsgálatát, a diaszpóra-, kisebbség-, gender-kutatások kérdéseit és az elmúlt évek tömegtüntetéseinek értelmezéseit. A harmadik kategóriába pedig azokat a paneleket soroltam, amelyek a kutatás és kutatott, társadalmi beágyazottság és globális beágyazottság kérdéseit firtatták. Vizsgálták a Romanian studies (románságtudományok) jelentőségét, tudományos kihívásait, az amerikai antropológusok kommunizmuskutatásait és azok hagyományait, a történeti archívumok, levéltárak használatának lehetőségeit, az akadémiai kutatói pályák kiszolgáltatottságát, a tudományos tudás intézményesítésének anomáliáit (például a plágium és a mühelyek problémáit, a tudományos fösodor müködésének, kialakulásának lehetőségeit).

Az első csoportba sorolt elöadások tehát azokat a folyamatokat elemezték, amelyek az 1918-as „Nagy Egyesülés” kontextusát adták, azoknak a müködését és nemzeti ambícióit, akik szerepet vállaltak a nemzeti mozgósításban. Ezek az előadások föleg Erdély és a Besszarábia romániai integrációjára fókuszáltak. A kortárs problémákat taglaló előadások már egy kelet-európai nemzetállam 21. századi jelenségeit tárták fel. Azonban itt is újra meg újra felmerült a Moldovai Köztársaság helyzete, az igény a helyi folyamatok és a két „román ország” közötti viszony megértésére. A harmadik csoport előadásai mutattak rá talán a legösszeszedettebb módon azokra a strukturális problémákra, amelyek többek között a tudományos vizsgálódás intézményesülésének az anomáliáiban, töréseiben érhetők tetten. Különösen inspiratívnak hatott a szervezőbizottság - az SRS - munkájának hozzákapcsolása a tudományos infrastruktúra kérdéséhez. Az önkritikus 
megnyilvánulások és az a szándék, hogy a konferencia szervezői saját funkciójukkal, történetükkel kapcsolatban fogalmazzanak meg állításokat, számomra az egyik legérzékenyebb és legérdekesebb része volt a rendezvénynek.

Ehhez az ethoszhoz kapcsolódott az egyik plenáris elöadás külföldi meghívottja, Katherine Verdery is, aki legutóbbi munkáiban a romániai állambiztonsági iratok alapján a róla írt anyagot dolgozta fel, egyfajta állambiztonsági szemüvegen át értelmezett autobiográfiát és társadalomtörténetet írva. Verdery saját kutatói pozíciójának és a román kommunizmus társadalmi kontextusának viszonyát járja körül munkájában, amelyet a személyesség és a totalitárius rendszer müködésének a megértésére tett erőfeszítések tesznek egyedivé. Ezúttal a román államépítés elkülönülő időszakait, ezen belül pedig a titkosszolgálat szerepét térképezte fel.

A másik plenáris előadást Vintilă Mihăilescu tartotta, aki Verderyhez hasonlóan az elmúlt száz év folyamatait elemezte, beemelve a román államot a Balkán-félsziget társadalomtörténetébe. Míg Verdery az államépítés, Mihăilescu a modernizáció és a vidék szempontjából tekintette át Románia száz évét.

A következő bekezdésekben azokat az előadásokat szeretném áttekinteni, amelyeket saját érdeklődési körömből fakadóan tartottam inspiratívnak, és a magyar olvasóközönség számára is relevanciával bírnak. Az „Are members of the Hungarian minority part of the Romanian political community?" elnevezésü panelt Salat Levente kolozsvári politológus szervezte. Myra Waterbury (Ohio University) a nemzeti kisebbségek többes kötődésének kérdését járta körül, az előző, a magyar könnyített honosításról folyó kutatásának folytatásaként. Bukarestben arról beszélt, hogy milyen „veszélyeket” rejt magában az erdélyi magyarok integrálódása a román és a magyar társadalomba. Mivel egyelöre a hipotézisek megfogalmazásának fázisában tart, az előadás inkább kérdéseket vetett fel. Irina Culic (Babeș-Bolyai Tudományegyetem) egy saját tapasztalataiból kibontakozó vizsgálatot tárt a közönség elé, arra keresve a választ, hogy az önálló állami magyar egyetem milyen helyzeteket lenne képes orvosolni, ahhoz a konfliktusos és sokszor tisztázatlan viszonyhoz képest, amelyet a mai Babeș-Bolyai Tudományegyetem vezetése és az oktatók között érzékelt. Sherrill Stroschein (University College London) székelyföldi önkormányzatokat vizsgált, a helyi politika és az országos hatalom közötti

REGIO 26. évf. (2018) 2. szám 222-226. 
viszonyt értelmezve. A panel utolsó előadója Kiss Tamás volt (Nemzeti Kisebbségkutató Intézet), ő a korrupcióellenes populizmus kontextusában helyezte el a kisebbségi közösségek politikai stratégiáinak kérdését. Az előadás szándéka szerint egy tágabb elméleti keretet kívánt teremteni (populizmus) az eddigi kutatási eredményeinek (kisebbségi integráció - aszimmetrikus akkomodációs modell), ami a munka jelenlegi fázisában még sok kérdést vet fel és sokfelé elágazhat.

Egy délutáni panel, amelyben szerzötársammal én is részt vettem, a Székelyföldet vette célba. A panel kissé provokatív címét - „The torn in the nation's flesh" - Egry Gábor (Politikatörténeti Intézet) találta ki. Egry előadásában Mócföld és Székelyföld mint periferikus régiók reprezentációját vetette össze, rámutatva több izgalmas nemzeti hitelességi stratégiára a két térség kapcsán, 1900 és 1944 között. Stefano Bottoni (MTA BTK TTI) a Sztálin a székelyeknél címü összegző munkájának egyfajta folytatásaként azt vizsgálta, hogy a Magyar Autonóm Tartományon belül milyen technikákon, stratégiákon keresztül valósult meg a kulturális-ideológiai munka. Egryhez hasonlóan a Zahorán Csabával (Trianon 100 MTA-Lendület Kutatócsoport) közösen tartott elöadásunkban szintén két periferikus régiót - határvidéket - hasonlítottunk össze. A Moldovai Köztársaságnak és Székelyföldnek a román hatalmi központhoz való viszonyát elemeztük, egyúttal pedig párhuzamot is vontunk a magyar állam Székelyföld, illetve a román állam Moldova felé irányuló támogatáspolitikájának helyi beágyazottsága között.

A moldovai témát több ponton is érintette a konferencia - az egyik legizgalmasabb esemény a fiatal történész, Andrei Cusco 2017-es könyvének bemutatója volt. Cusco a román és orosz Besszarábia-képeket elemezte a 19. század végétő a 20 . század elejéig. A munkát forrásgazdagsága, elméleti keretezése és a téma alapos feldolgozása miatt Sorin Antohi kimagasló teljesítményként dicsérte.

A centenáriumi konferencián markánsan megjelent a Moldovai Köztársaság és Románia történetének összefonódása, ráirányítva a figyelmet a román nemzeti egység kérdésérére is. Ezt jól szemléltette az emlékezet és a felelősség viszonyát boncolgató panel (az University College Cork-ról, James Kapalo vezetésével), a NagyRomániára való emlékezést és ennek identitáskonstituáló szerepét vizsgáló szekció (Monica Ciobanu, State University of New York és

REGIO 26. évf. (2018) 2. szám 222-226. 
egy hasonló szekció, Michaela Serban, USA-Ramapo University-röl elnöklésével), valamint a két világháború közötti innocentista vallási közösségek földalatti hálózatainak ellenálló tevékenységével foglalkozó előadások (az Universitatea Sincai-ról, Marosvásárhelyről, Ionuț Biliuță vezetésével). A múlt feltárásához való jog keretezése Kelet-Európában (pl. restitúciós törvények és tervezetek, kártérítések, az állambiztonsági iratokhoz való hozzáférés és a levéltárak kutathatósága stb.), az emlékezésre vonatkozó nyilvános diskurzusok, a múlt újraélésének különböző terepei az előadások során úgy a román, mint a moldovai kontextusban elemzésre kerültek.

A konferencia előadásainak, vitáinak túlnyomó többségére jellemző volt az a törekvés, hogy az adott kutatási témán túl meg tudjanak fogalmazni valamilyen reflexiót a mai romániai viszonyokra és a kutatói pozícióra nézve is. Ez mutatja az igényt a tudomány és tudományos viták presztízsének helyreállítására. Ilyen értelemben nem csoda, hogy az esemény méretei és a nemzetközi elismerésnek örvendő előadók ellenére a helyi és országos politika (valamint a román akadémiai vezetés) távol maradt az eseménytől. A kritikai nézőpont érvényesítése mellett fontos szempont maradt az elöadásokban a saját pozíciók meghatározása. Számomra a légkör, a viták hangvétele és az előadásokat kísérő beszélgetések is kifejezetten inspiratívak voltak.

REGIO 26. évf. (2018) 2. szám 222-226. 